\title{
Judicialization of health arising from prepaid insurance plans and health law: an integrative review
}

\author{
Judicialização da saúde decorrente dos planos de pré-pagamento e o direito sanitário: revisão integrativa \\ Judicialización de la salud resultante de los planes de prepago y el derecho sanitario: revisión integrativa
}

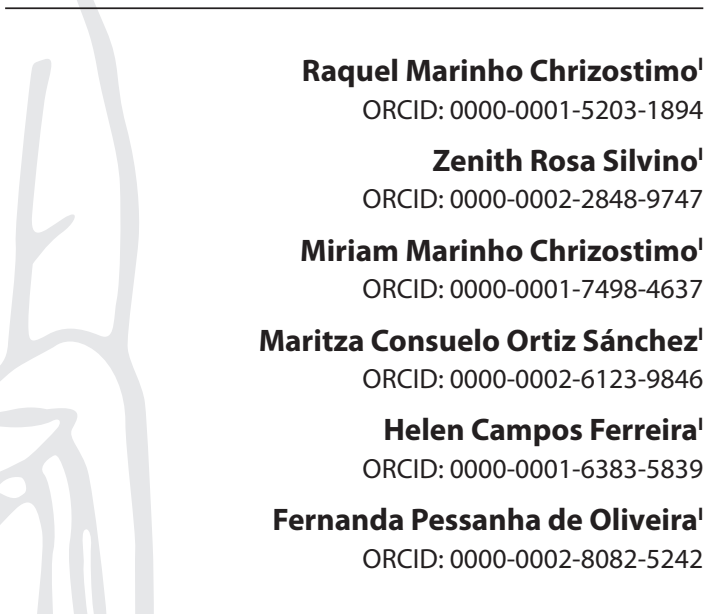

'Universidade Federal Fluminense. Niterói, Rio de Janeiro, Brazil.

How to cite this article: Chrizostimo RM, Silvino ZR, Chrizostimo MM, Sánchez MCO Ferreira HC, Oliveira FP. Judicialization of health arising from prepaid insurance plans and health law: an integrative review. Rev Bras Enferm. 2020;73(3):e20180400. doi: http://dx.doi.org/10.1590/0034-7167-2018-0400

Corresponding author:

Raquel Marinho Chrizostimo

E-mail:rm.chrizostimo@gmail.com

EDITOR IN CHIEF: Dulce Aparecida Barbosa ASSOCIATE EDITOR: Alexandre Balsanell

Submission: 06-12-2018

Approval: 04-16-2019

\section{ABSTRACT}

Objective: To analyze publications regarding judicial demands related to the violation of the rights of the client who uses private health insurance in Brazil. Method: Integrative review, from September to October 2017, of national character, with complete texts online, in Portuguese and English, published between 2012 and 2017 in the Virtual Health Library portal, excluding studies that were duplicated or with indiscriminate methodology. Results: The judicial demands were for: medication (32\%); ward hospitalization (11\%); surgical procedures (9\%); orthosis, prothesis and special materials (9\%); others (9\%); and diagnostic procedures, outpatient service, hospitalization in Intensive Care Units, food formulas and disposable diapers (30\%). Conclusion: The prevalence of legal disputes arising from the failure in providing health service by private health insurances was observed, which makes it easier for the administrators to identify the sought health products and services in order to reorganize the administrative sphere and provide quality care.

Descriptors: Judicial Action; Choice of Health Care Provider Laws; Constitutional Law; Prepaid Health Plans; Community Health Systems.

\section{RESUMO}

Objetivo: Analisar as publicações a respeito de demandas judiciais relacionadas à infração aos direitos do usuário que utiliza plano privado de saúde no Brasil. Método: Revisão integrativa de setembro a outubro de 2017, com caráter nacional em português e inglês, textos online completos e publicados entre 2012 e 2017 no Portal da Biblioteca Virtual em Saúde, excluindo os duplicados e com metodologia indiscriminada. Resultados: As demandas judiciais foram: $32 \%$ medicamentos; $11 \%$ internação em enfermaria; $9 \%$ procedimentos cirúrgicos; $9 \%$ órtese, prótese e materiais especiais; $9 \%$ outros; e $30 \%$ de procedimentos diagnósticos, atendimento ambulatorial, internação em Centro de Terapia Intensiva, fórmulas alimentares e fraldas descartáveis. Conclusão: Demonstra-se a prevalência dos litígios judiciais decorrentes da falha na prestação do serviço de saúde pelos planos privados, o que facilita aos gestores identificar produtos e serviços de saúde pleiteados para reorganização da esfera administrativa e prestação de assistência com qualidade.

Descritores: Judicialização da Saúde; Direito Sanitário; Direito Constitucional; Planos de Pré-Pagamento em Saúde; Sistema Único de Saúde.

\section{RESUMEN}

Objetivo: Analizar las publicaciones acerca de las demandas judiciales relacionadas con la infracción a los derechos del usuario que utiliza un plan privado de salud en Brasil. Método: Revisión integrativa realizada entre septiembre y octubre de 2017, en ámbito nacional en los idiomas portugués e inglés, con textos completos y publicados en línea de 2012 a 2017 en el Portal de la Biblioteca Virtual en Salud, con la exclusión de los duplicados y de metodología indiscriminada. Resultados: Las demandas judiciales fueron: un 32\% por medicamentos; un $11 \%$ por internación en enfermería; un $9 \%$ por procedimientos quirúrgicos; un $9 \%$ por ortesis, prótesis y materiales especiales; un $9 \%$ por otros; y un 30\% por procedimientos diagnósticos, de atención ambulatoria, de internación en un Centro de Terapia Intensiva, de fórmulas alimentarias y pañales desechables. Conclusión: Se demostró una prevalencia de los litigios judiciales resultantes de una falla en la prestación del servicio de salud por los planes privados, lo que les facilita a los gestores identificar los productos y servicios de salud necesarios para reorganizar la esfera administrativa y la prestación de una asistencia con calidad.

Descriptores: Judicialización de la Salud; Derecho Sanitario; Derecho Constitucional; Planes de Salud de Prepago; Sistema Único de Salud. 


\section{INTRODUCTION}

Within health law, the obligation of the State is to ensure full, universal and free access to health services, as described by the basic premises of the Brazilian Unified Health System (SUS) ${ }^{(1)}$. This is a fundamental right, defined as subjective legal position of a field of action and free, with the establishment of withdrawal or limitation to state or private activity, or causing the possibility — due to its ownership — of demanding positive installments of the state ${ }^{(2)}$.

The creation of the SUS, through the Federal Constitution of $1988^{(3)}$, and its regulation by the Organic Health Law aimed at the reorganization of the health system in order to ensure the access to the right to health, seeking to modify the situation of inequality in health care through the mandatory public service to any individual, prohibiting the collection of any amount for the service provided ${ }^{(1,4)}$.

In this way, the principle of equity stands out in meeting the health needs of the population, offering quality services adapted to their needs, regardless of the purchasing power of the individual. However, although SUS has structured legal framework and intends to assist the population equally, the access to the system still constitute a challenge that refers to universalization, financing, to the institutional model, the model of care, work management and to social participation ${ }^{(5)}$.

In order to improve access, the participation of the private sector in SUS is evident through contracts and service agreements in circumstances in which the public health care units are insufficient to ensure full service to individuals. Despite the already described initiatives, in view of the remediation of the precariousness of services, shortage of vacancies and resoluteness in the public healthcare system, a growing portion of the population is seeking assistance through health care plans. These act in the sphere denominated "supplementary health" and provide services through specialized legal entities, called health insurance operators ${ }^{(1)}$.

Law no. 9,656 from June $31998^{(6)}$, disciplines health insurance plans and was changed by some interim measures (IM), until the IM no. 2,177-44(7), of 24 August 2001, was created, which is still in effect. The National Regulatory Agency for Private Health Insurance (ANS - Agência Nacional de Saúde Suplementar) ${ }^{(8)}$ also has an important role in this context, so that the body may be responsible for the regulation, standardization, control and supervision of the activities carried out by health insurance plans. In this way, the ANS should regulate the relationship between users and providers of health services, aiming, among other things, at minimizing consumer law violations, since health insurance plans can deny providing services ${ }^{(8)}$.

In these circumstances, since it is impossible to solve the conflict at the administrative level, those interested have to seek the judicial sector to obtain the medicine or treatment denied by the health system, a theme named "judicialization of health"(9). To solve these actions, judges and professionals whose area of technical expertise is not health become responsible.

Situations in which users resort to judicialization of health have become increasingly common. Only in December 2017, there was more than three thousand cases in which the beneficiaries of health insurance plans appealed to Justice to obtain the provision of service of product ${ }^{(10)}$, which justifies this research.

Faced with constitutional guarantees and with sanitary law, which comprises the judicialization of health, there is an evident relevance of conducting researches that consider reaching the international public, which may know the topic of the study. One also has to consider the description of the judicial demands made explicit in scientific productions with the obstacles to the right to health, particularly as regards the lack of access of the beneficiaries to products and services. Thus, the research question that guided this study was: what are the judicial demands arising from the violation to the rights of the client who uses private health insurance plans evidenced in scientific productions?

It is worth highlighting the limitation of the study, which includes several formats of scientific production in the sphere of research elements for publication and, among other aspects, it is seen that not all journals request the same data: therefore, data collection, analysis and results are impaired, which hinders the correlation of the research data for the perfect result in reaching the most comprehensive picture.

\section{OBJECTIVE}

To analyze publications regarding judicial demands related to the violation of the rights of the client who uses private health insurance in Brazil.

\section{METHOD}

This research is a Bibliographic, integrative literature review with explanatory descriptive methodological approach, performed from September to October 2017. To develop this study, eight steps were conducted: 1 ) identification of the topic and formulation of the guiding question; 2) establishment of study inclusion and exclusion criteria; 3 ) defining the research databases; 4) defining the resources of bibliographic search; 5 ) defining information to be extracted from the selected studies; 6 ) assessment of the included studies; 7) interpreting the results; and 8) showing the review $^{(11)}$. The research was performed through the Virtual Health Library portal (BVS - Biblioteca Virtual em Saúde). The choice of this portal is related to the local character of the research, based on the Brazilian legislation on health rights, which is why no international databases were assessed.

Therefore, articles indexed from different databases were recovered, such as: Latin American and Caribbean Center on Health Sciences Information (LILACS), Online Medical Literature Analysis and Retrievel System (MEDLINE), National Collection of Information Sources of the Unified Health System (Coleciona SUS), Nursing Database (BDENF - Enfermagem), Healthy Cities (CidSaúde), History of Health (HISA) and the Cuban National Center of Information of Medical Sciences (CUMED).

The inclusion criteria were: scientific articles in Portuguese and English, published from 2012 to 2017, with complete texts available online and a national character in its object. Exclusion criteria were: review articles or bibliographic research of different types, repeated documents in different databases, and articles without discriminated methodology. 
The following descriptors were used, from the Health Sciences Descriptors (DECs - Descritores em Ciências da Saúde) of the BVS: Judicialização da Saúde, Direito Sanitário, Direito Constitucional, Planos de Pré-Pagamento em Saúde, and Sistema Único de Saúde. In Spanish: Judicialización de la Salud, Derecho Sanitario, Derecho Constitucional, Planes de Salud de Prepago and Sistema Único de Salud. As well as the descriptors from the Medical Subject Headings (MeSH), in English: Judicial Action, Choice of Health Care Provider Laws, Constitutional Law, Health Insurance and Community Health Systems.

The Boolean operators "and" and "or" were used in five search strategies (Figure 1), which allowed us to find 117 articles. The definition of the information to be extracted from the evidences of scientific productions was based on the judicial demands of the violation of the rights of the client who uses a private health insurance. The evaluation of the included studies was performed according to the inclusion and exclusion criteria, and the recordings had the following items: name(s) of the author(s), article title, name of the journal, topic approached, year of publication, methodology used and proposed objectives. In this way, the findings of the search were refined.

In the analysis stage, the process took place through the analytical reading of the selected scientific productions. Then, they were subjected to rigorous content analysis to verify the adhesion to the proposed thematic. Later, the health products and health arising from judicial demands were described. Finally, the frequency of the judicial proceedings was verified and the congruence of the research with data encoding and interpretation was explored in order to expose the results. After this stage, 14 articles were included, which met entirely the proposed methodological rigor (Chart 1).

As knowledge domain, the following subjects were chosen: consumer protection; health services accessibility; supplementary health; unified health system; health law; right to health; constitutional health; and health insurance plans.

\section{RESULTS}

The search strategy resulted in 117 scientific productions (according to Figure 1), which made it possible to have as product 14 tracked studies, assessed for readability and included in the research, which comprise $100 \%$ of the sample, as shown in Chart 1, named "articles included in the study". Such chart brings the variables: item; year; title of the scientific productions identified by PC $1^{(12)}$,
PC $2^{(13)}, P C 3^{(14)}$ and so on until PC15(26), with the proviso that the PC $2^{(13)}$, Luzuriaga ${ }^{(13)}$ (2014), was excluded for showing an international character in its objects; author and origin, distinguished by superscript number from 12 to 26 (with emphasis on the fact that the number 13 corresponded to PC 2); journal; objective; and type of study or methodological approach. Thus, the data confirm the information of the sample.

The result shows that the productions with relation to the authors and origin are distributed as follows: 37 authors, who represent $100 \%$; nine from Rio de Janeiro-RJ (24.4\%); seven from Belo Horizonte-MG (18.9\%); seven from São Paulo-SP (18.9\%); four from Itajaí-SC (10.8\%); two from Florianópolis-SC (5.4\%); eight from Salvador-BA, FortalezaCE, London (England), Brasília-DF, Santos-SP, Juiz de Fora-MG and São João de Boa Vista-SP, each author with $2.7 \%$, and $21.6 \%$ in total(12,14-26).

Regarding the year of publication, five are from 2014 (35.7\%); four from 2016 (28.6\%); two from 2013 (14.3\%); and one in each of the years of 2010, 2012 and 2015 (21.4\%).

It is also evident that the criterium related to the language in $100 \%$ of the articles, in which $92.8 \%$ represent 13 studies published in Portuguese, and one, or 7.2\%, in English.

Regarding the journals, the analysis shows that, from the 14 articles (100\%), seven (50\%) are from the Revista de Direito Sanitário; one (7.2\%) from the Cadernos de Saúde Pública; and six (42.8\%) from the journals Bioética, Administração Pública, Enfermagem UERJ, Acta Scientiarum Health Sciences, Saúde Pública do SUS/MG and Cuidarte, with an article in each of them ${ }^{(12,14-26)}$. 
Chart 1 - Articles included in the study

\begin{tabular}{|c|c|c|c|c|}
\hline Title & Author/Origin & $\begin{array}{l}\text { Year/ } \\
\text { Journal }\end{array}$ & Objective & $\begin{array}{l}\text { Type of study or } \\
\text { methodological } \\
\text { approach }\end{array}$ \\
\hline $\begin{array}{l}\text { The problem involving OPMEs } \\
\text { and the health plans contracts: } \\
\text { outline and analysis of the issue } \\
\text { PC1 }\end{array}$ & $\begin{array}{l}\text { Martins, Paulo Roberto do } \\
\text { Nascimento (Porto Alegre/ } \\
\text { RS); Dahinten, Bernardo } \\
\text { Franke (Porto Alegre/ } \\
\text { RS); Dahinten, Augusto } \\
\text { Franke (Porto Alegre/RS) }{ }^{(12)}\end{array}$ & $\begin{array}{l}2016 \\
\text { Revista } \\
\text { de Direito } \\
\text { Sanitário }\end{array}$ & $\begin{array}{l}\text { To introduce and analyze some of most } \\
\text { polemic issues involving the indications } \\
\text { of orthoses, prosthetics and special } \\
\text { materials (OPSMs) within health plans } \\
\text { contracts. }\end{array}$ & $\begin{array}{l}\text { Documentary } \\
\text { study }\end{array}$ \\
\hline $\begin{array}{l}\text { Evaluation of patient's } \\
\text { satisfaction in a public-private } \\
\text { health facility in Northeastern } \\
\text { Brazil and the judicialization of } \\
\text { healthcare } \\
\text { PC3 }\end{array}$ & $\begin{array}{l}\text { Silva Junior, Geraldo Bezerra } \\
\text { da (Salvador/Bahia); Dias, } \\
\text { Eduardo Rocha (Fortaleza/ } \\
\text { CE) }\end{array}$ & $\begin{array}{l}2016 \\
\text { Revista } \\
\text { de Direito } \\
\text { Sanitário }\end{array}$ & $\begin{array}{l}\text { To analyze the degree of satisfaction } \\
\text { of users of a public-private healthcare } \\
\text { service in the Northeast of Brazil, as well } \\
\text { as their level of knowledge about their } \\
\text { rights and about the judicial procedure } \\
\text { used to guarantee these rights. }\end{array}$ & $\begin{array}{l}\text { Cross-sectional } \\
\text { study }\end{array}$ \\
\hline $\begin{array}{l}\text { Judicialization of health and } \\
\text { institutional dialogue: the } \\
\text { experience of the city of Lages } \\
\text { (State of Santa Catarina, Brazil) } \\
\text { PC4 }\end{array}$ & $\begin{array}{l}\text { Asensi, Felipe (Rio de Janeiro/ } \\
\text { RJ); } \\
\text { Pinheiro, Roseli (Rio de Janeiro/ } \\
\text { RJ)(15) }\end{array}$ & $\begin{array}{l}2016 \\
\text { Revista } \\
\text { de Direito } \\
\text { Sanitário }\end{array}$ & $\begin{array}{l}\text { To analyze the interaction between the } \\
\text { Judicial Branch, health professionals and } \\
\text { the representatives in realizing the right } \\
\text { to health. }\end{array}$ & Case study \\
\hline $\begin{array}{l}\text { Legalization of health: analyzing } \\
\text { public hearing in the Brazilian } \\
\text { Supreme Federal Court } \\
\text { PC5 }\end{array}$ & $\begin{array}{l}\text { Machado, Teresa Robichez } \\
\text { de Carvalho (Rio de Janeiro/ } \\
\text { RJ)(16) }\end{array}$ & $\begin{array}{l}2014 \\
\text { Revista } \\
\text { Bioética }\end{array}$ & $\begin{array}{l}\text { To analyze the public hearing on health } \\
\text { judicialization, convened in } 2009 \text { by } \\
\text { the Brazilian Supreme Federal Court, } \\
\text { according to the theoretical framework } \\
\text { of Nancy Fraser. }\end{array}$ & $\begin{array}{l}\text { Documentary } \\
\text { study }\end{array}$ \\
\hline $\begin{array}{l}\text { Access to medium and high- } \\
\text { complexity procedures in } \\
\text { the Brazilian Unified National } \\
\text { Health System: a matter of } \\
\text { judicialization } \\
\text { PC6 }\end{array}$ & $\begin{array}{l}\text { Gomes, Fernanda de Freitas } \\
\text { Castro (Belo Horizonte/ } \\
\text { MG); Cherchiglia, Mariângela } \\
\text { Leal (Belo Horizonte/ } \\
\text { MG); Machado, Carlos Dalton } \\
\text { (Belo Horizonte/MG); Santos, } \\
\text { Viviane Cristina dos (Belo } \\
\text { Horizonte/MG); Acurcio, } \\
\text { Francisco de Assis (Belo } \\
\text { Horizonte/MG);Andrade, Eli lola } \\
\text { Gurgel (Belo Horizonte/MG)(17) }\end{array}$ & $\begin{array}{l}2014 \\
\text { Cadernos de } \\
\text { Saúde Pública }\end{array}$ & $\begin{array}{l}\text { To analyze the use of court action to } \\
\text { ensure access to outpatient and hospital } \\
\text { procedures from } 1999 \text { to } 2009 \text { in the } \\
\text { State of Minas Gerais, Brazil. }\end{array}$ & $\begin{array}{c}\text { Retrospective } \\
\text { descriptive study }\end{array}$ \\
\hline $\begin{array}{l}\text { The principles of universality } \\
\text { and integrality of the Brazilian } \\
\text { National Public Health System } \\
\text { from the perspective of the } \\
\text { policy for rare diseases and the } \\
\text { incorporation of technological } \\
\text { resources } \\
\text { PC7 }\end{array}$ & $\begin{array}{l}\text { Aith, Fernando (São Paulo/ } \\
\text { SP); Dallari, Sueli Gandolfi } \\
\text { (São Paulo/SP); Nascimento, } \\
\text { Paulo Roberto do (São Paulo/ } \\
\text { SP); Bujdoso, Yasmim (São } \\
\text { Paulo/SP) }\end{array}$ & $\begin{array}{c}2014 \\
\text { Revista } \\
\text { de Direito } \\
\text { Sanitário }\end{array}$ & $\begin{array}{l}\text { To analyze, from the current legal form, } \\
\text { how the Committee for Technological } \\
\text { Development acts to incorporate new } \\
\text { technologies into the Brazilian National } \\
\text { Health System and the policy for drugs to } \\
\text { patients who suffers of rare diseases. }\end{array}$ & $\begin{array}{l}\text { Documentary } \\
\text { study }\end{array}$ \\
\hline $\begin{array}{l}\text { The impacts of health care } \\
\text { judicialization in the city of Sao } \\
\text { Paulo: public expenditure and } \\
\text { federal organization } \\
\text { PC8 }\end{array}$ & $\begin{array}{l}\text { Wang, Daniel Wei L (London/ } \\
\text { England); Vasconcelos, } \\
\text { Natália Pires de (São Paulo/ } \\
\text { SP); Terrazas, Fernanda Vargas } \\
\text { (Brasília/DF); Oliveira, Vanessa } \\
\text { Elias de (São Paulo/SP) }{ }^{(19)}\end{array}$ & $\begin{array}{c}2014 \\
\text { Revista de } \\
\text { Administração } \\
\text { Pública }\end{array}$ & $\begin{array}{l}\text { To analyze the impact of judicial } \\
\text { decisions for the budgetary management } \\
\text { of health policy in the city of Sao Paulo. }\end{array}$ & Case study \\
\hline $\begin{array}{l}\text { Judicialization of health, } \\
\text { problem and solution: issues for } \\
\text { nursing } \\
\text { PC9 }\end{array}$ & $\begin{array}{l}\text { Carvalho, Eloá Carneiro (Rio } \\
\text { de Janeiro/RJ); David, Helena } \\
\text { Maria Scherlowski Leal (Rio } \\
\text { de Janeiro/RJ) }{ }^{(20)}\end{array}$ & $\begin{array}{c}2013 \\
\text { Revista } \\
\text { Enfermagem } \\
\text { UERJ }\end{array}$ & $\begin{array}{l}\text { to reflect on the phenomenon of } \\
\text { legalization, discussing the dignity of the } \\
\text { human person as a value and the right } \\
\text { to health as a republican principle, both } \\
\text { guaranteed by the Constitution. }\end{array}$ & $\begin{array}{l}\text { Theoretical- } \\
\text { reflective study }\end{array}$ \\
\hline $\begin{array}{l}\text { Judicial litigations and social } \\
\text { welfare: access to medicines in } \\
\text { two towns in the Santa Catarina } \\
\text { State, Brazil } \\
\text { PC10 }\end{array}$ & $\begin{array}{l}\text { Leite, Silvana Nair } \\
\text { (Florianópolis/SC); Schaefer, } \\
\text { Cristine (Itajaí/Santa } \\
\text { Catarina); Fittkau, Kelly (Itajaí/ } \\
\text { SC) }\end{array}$ & $\begin{array}{l}2012 \\
\text { Acta } \\
\text { Scientiarum } \\
\text { Health } \\
\text { Sciences }\end{array}$ & $\begin{array}{l}\text { To characterize the supply of requested } \\
\text { drugs by judicial process two towns with } \\
\text { different socioeconomic characteristics } \\
\text { and different municipal pharmaceutical } \\
\text { service organizations. }\end{array}$ & $\begin{array}{l}\text { Documentary } \\
\text { study }\end{array}$ \\
\hline
\end{tabular}




\begin{tabular}{|c|c|c|c|c|}
\hline Title & Author/Origin & $\begin{array}{l}\text { Year/ } \\
\text { Journal }\end{array}$ & Objective & $\begin{array}{l}\text { Type of study or } \\
\text { methodological } \\
\text { approach }\end{array}$ \\
\hline $\begin{array}{l}\text { The judicialization of access to } \\
\text { medicines in Santa Catarina State: } \\
\text { a challenge for the management } \\
\text { of the health system } \\
\text { PC11 }\end{array}$ & $\begin{array}{l}\text { Boing, Alexandra (Florianópolis/ } \\
\text { SC) Catarina); Bloemer, Neusa } \\
\text { Sens (Itajaí/SC); Roeler, Cláudia } \\
\text { (Itajaí/SC); Fernandes, Simone } \\
\text { (Santos/SP) }\end{array}$ & $\begin{array}{c}2013 \\
\text { Revista } \\
\text { de Direito } \\
\text { Sanitário }\end{array}$ & $\begin{array}{l}\text { To analyze the granted court orders that } \\
\text { requested medication and were filed } \\
\text { against the State of Santa Catarina from } \\
2000 \text { to } 2006 \text {. }\end{array}$ & $\begin{array}{l}\text { Documentary } \\
\text { study }\end{array}$ \\
\hline $\begin{array}{l}\text { Profile of the demand for legal } \\
\text { right to public health of the } \\
\text { municipality of Leopoldina-MG } \\
\text { PC12 }\end{array}$ & $\begin{array}{l}\text { Oliveira, Renan Guimarães de } \\
\text { (Belo Horizonte/MG); Souza, } \\
\text { Auta Iselina Stephan (Juiz de } \\
\text { Fora/MG) }\end{array}$ & $\begin{array}{l}2014 \\
\text { Revista de } \\
\text { Saúde Pública } \\
\text { do SUS/MG }\end{array}$ & $\begin{array}{l}\text { To establish an analysis of the } \\
\text { justiciability of the right to public health } \\
\text { in the city of Leopoldina-MG. }\end{array}$ & Case study \\
\hline $\begin{array}{l}\text { The judicialization of public } \\
\text { health in Brazil: a study of social } \\
\text { representations } \\
\text { PC13 }\end{array}$ & $\begin{array}{l}\text { de Souza Ramos, Raquel (Rio } \\
\text { de Janeiro/RJ); Tosoli Gomes, } \\
\text { Antonio Marcos (Rio de } \\
\text { Janeiro) }\end{array}$ & $\begin{array}{l}2010 \\
\text { Revista } \\
\text { Cuidarte }\end{array}$ & $\begin{array}{l}\text { To describe and discuss the structure of } \\
\text { social representations of the judicialization } \\
\text { of health activities and services within } \\
\text { the Unified Health System by health } \\
\text { professionals involved in the process of } \\
\text { legalization of health. }\end{array}$ & $\begin{array}{l}\text { Qualitative } \\
\text { approach }\end{array}$ \\
\hline $\begin{array}{l}\text { The institutional interface between } \\
\text { Brazilian Regulatory Agency for } \\
\text { Private Health Insurance and } \\
\text { Judiciary: analysis of judicial } \\
\text { cases about medical care for } \\
\text { emergencies in healthcare plans } \\
\text { PC14 }\end{array}$ & $\begin{array}{l}\text { Ramalho, Bruno Araujo (Rio } \\
\text { de Janeiro/RJ)(25) }\end{array}$ & $\begin{array}{c}2016 \\
\text { Revista } \\
\text { de Direito } \\
\text { Sanitário }\end{array}$ & $\begin{array}{l}\text { To analyze the judicial control of the } \\
\text { regulations adopted by the Brazilian } \\
\text { National Regulatory Agency for Private } \\
\text { Health Insurance and Plans (ANS) in relation } \\
\text { to cases involving medical emergency } \\
\text { coverage in health care insurance plans. }\end{array}$ & $\begin{array}{l}\text { Documentary } \\
\text { study }\end{array}$ \\
\hline $\begin{array}{l}\text { Analysis of individual lawsuits on } \\
\text { supplying medication in São João } \\
\text { da Boa Vista, São Paulo, Brazil } \\
\text { PC15 }\end{array}$ & $\begin{array}{l}\text { Cabral, Ildelisa (São João da } \\
\text { Boa Vista/SP); Rezende, Laura } \\
\text { Ferreira de(São Paulo/SP) }\end{array}$ & $\begin{array}{c}2015 \\
\text { Revista } \\
\text { de Direito } \\
\text { Sanitário }\end{array}$ & $\begin{array}{l}\text { To analyze the individual lawsuits filed } \\
\text { to guarantee access to medication in the } \\
\text { city of São João da Boa Vista, São Paulo } \\
\text { State, Brazil. }\end{array}$ & $\begin{array}{l}\text { Documentary } \\
\text { study }\end{array}$ \\
\hline
\end{tabular}

In the objectives, it must be considered that the introduction, analysis, investigation, reflection, characterization, establishment, discussion and the description of judicialization of health actions and services within the scope of health insurance plans and of SUS are pertinent to this research, considering the principle of universality in the right to health in order to ensure the health of the population ${ }^{(12,14-26)}$.

Regarding the types of research or methodological approach, it was verified that: seven are documentary (50\%); three are case studies (21.4\%); four comprise different types of study or methodological approach, being one qualitative approach, one cross-sectional study, a retrospective descriptive and a theoreticalreflective study $(28.6 \% \text {, each representing } 7.15 \%)^{(12,14-26)}$.

Therefore, $100 \%$ of the publications discuss Brazilian realities. However, 12 of them, which corresponds to $85.7 \%$, discuss local realities, namely: from the Northeast of Brazil, from July to November 2014; from Lages, in Santa Catarina, in 2013 and 2014; from the state of Minas Gerais, from February to November 2009; from Minas Gerais from 2008 to 2012; from the municipality of São Paulo, in 2009; from the municipalities of Blumenau and Aurora, in Santa Catarina, in 2006 and 2007; from the state of Santa Catarina, between 2000 and 2006; from the municipality of Leopoldina, in Minas Gerais, from January to December 2012; from the states of Rio de Janeiro, Minas Gerais and São Paulo, on April 12 2015; from São João da Boa Vista, in São Paulo, from 2009 to 2012; from the state of Rio de Janeiro, between 2000 and 2012; and from the state of Rio de Janeiro, from August to November 2013. The remaining two (14.3\%) approach issues on judicialization of health focused on Brazil in general ${ }^{(12,14-26)}$.

Given this context, for the continuity of the analysis of scientific productions, the guiding question was sought: what are the judicial demands resulting from the violation of the rights of the client who uses a private health plan and who are listed in scientific productions? The following judicial demands were found: $32 \%$ for medications; $11 \%$ for ward hospitalization; $9 \%$ for surgical procedures; $9 \%$ for OPSM; $9 \%$ for others; and 30\% divided in diagnostic procedures, outpatient service, hospitalization in Intensive Care Units (ICU), food formulas and disposable diapers, and each described item represents 6\% $\%^{(12,14-26)}$, as shown by Figure 2 .

Thus, the results are shown according to the judicial demands that are in the following variables: health products, services and others, with this, N is considered 10 . In health products, N is 1, being $100 \%$, because the OPSMs were joined. In health services, $\mathrm{N}$ is 8 , totaling $100 \%$, considering eight items considered in Figure 2, subdivided in: medications; hospital beds for hospitalization in a ward or ICU; diagnostic and surgical procedures; general and specialized consultations; food formulas; and diapers. The other Ns, equal to 1, represent $100 \%$ and refer to resource allocation, function and interconnection between the three powers ${ }^{(12-26)}$.

Therefore, the relevance is in the frequency related to health services, which has $80 \%$ with eight mentions in comparison with other variables, health products and others, which were $10 \%$ each, totaling $20 \%$.

However, among health services, the difficulty of the individuals in the access to medication predominates - according to the references above - therefore, this item appears with high frequency in scientific production. However, the access to hospitalization in wards and ICU, to surgical and diagnostic procedures, to outpatient treatment, to food formulas and to disposable diapers is still problematic. 


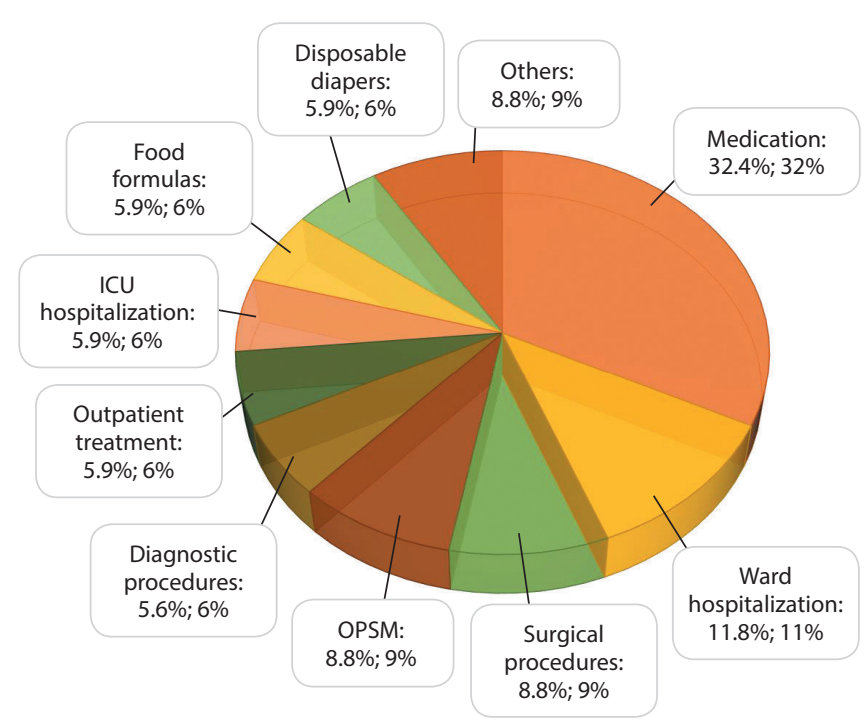

Figure 2 - Judicial demands

\section{DISCUSSION}

When checking the judicial demands resulting from health insurance plans, health products and services are mentioned in the scientific productions ${ }^{(12,14-18,21-26)}$, as well as the demands within the administrative sphere in relation to resource allocation and the function of interconnection between the three branches of the Government ${ }^{(19-20)}$

In health products, orthoses, prostheses and special materials were cited. In the procedures, examination; general and specialized consultations; and hospital beds - including ICU(12,14-18,21-26). In others, there was a mention of resource allocation, function and interconnection between the three powers ${ }^{(19-2)}$.

There is consistency in the research, because both the health product and service need resource allocation, a clear and objective function in the spheres of government with relation to the role along with health plans and interconnection between the three spheres of government. The lack of access to health products, such as OPSM, affects the individual, family and society as much as health services ${ }^{(12,14-26)}$.

As regards the judicialization and the demands for products and services, the individual uses the judicial system to get what they need to regain their health. In this case, it is inferred that the ANS, as mediator between the health plans and users, should be activated to resolve the cases.

However, what the productions ${ }^{(12,14-26)}$ show is that it is necessary to resort to Justice in order to have access to products and services offered by private health insurance plans, which makes one realize that these judicial decisions affect the government administration if the health insurance plan does not meet these demands, as evidenced in the lawsuits that request the provision of medicines, supplies and medical treatments for the patients, in addition to bids for those products that the Secretariat will have to provide by judicial order, thus anticipating and rationalizing the expenditure ${ }^{(24)}$.

It is noted that, both in SUS and in the supplementary health system, the individuals seek a solution for their problems. Frequently, they are faced with the denial of constitutionally guaranteed rights, which brings a new and important point of view to the discussion of the term: that the judicialization of health derives from a denied social right, being, in this study, the right to health.

It is thought that the judiciary has been receptive to individual demands that claim the provision of medicines, supplies and health treatments by SUS ${ }^{(25)}$. For the state to implement the right to life, it must implement public policies with democracy, but it is not for the legal order to determine its content, but to enunciate interpretative principles, disposing on their guardianship through freedom and guarantees that assure them ${ }^{(26)}$.

The reflection on health services and judicial demands is related to the aging of the population and the high prevalence of diseases that require continuous and costly treatment. However, there is in legislation a legal framework that considers the fundamental aspects and of the protection of the individual generically regarding the social rights par excellence and the right to health.

With these assumptions, it is known that social rights seek the quality of life for individuals, however, although they are interconnected, it is necessary to emphasize and distinguish the differences between social and individual rights.

Social rights, as a dimension of the fundamental rights of man, are benefits adjusted by the state directly or indirectly, issued in constitutional norms that approve living conditions appropriate to those in need, rights that tend to perform social equity to the unequal, thus, they are rights that are linked to the right of equality.

Social rights are subject to the actions of the state, which is why part of these norms has a limited effectiveness. Still, they defend as conjecture the enjoyment of individual rights, to the extent that they create material conditions favorable to the benchmarking of real identity, which, in turn, harmonizes the condition conjugated with the effective exercise of freedom.

The Federal Constitution of $1988^{(3)}$ had a particular concern regarding the social rights of Brazilians, when it established the devices that would ensure to the citizen all the necessary basics, so they have a dignified existence and working conditions.

Regarding the judicialization and the demands related to administrative questions, health is a social right of the Brazilian citizen, however, only from the $20^{\text {th }}$ century, with the emergence of the World Health Organization (WHO) ${ }^{(27)}$, is that health was defined as the complex of the physical, mental and social wellbeing, and not only as the absence of diseases or injuries. It was also recognized as one of the fundamental rights of every human being, regardless of their social or economic conditions and religious or political beliefs.

This study focused on Brazilian legislation, but the research might reach different publics, both inside the country and internationally. Thus, the valuable mention to health as basic right of every Brazilian citizen, as everywhere in the world, is necessary. Health is related to education regarding the individual, considering that, through education, several problems could be avoided. Knowledge brings the understanding that the relentless pursuit for biopsychosocial and spiritual balance is of utmost importance, as well as the balance between environmental influences and lifestyle, among other factors.

\section{Limitations of the study}

The limitation of the study is related to the connection between research data. The scientific productions are in different formats 
in the sphere of research elements for publication. Therefore, not all journals request the same data, so that their collection, analysis and results are damaged, which hinders the correlation of the research data for the perfect result in range of the most comprehensive panorama. The deepening of the discussion and the richness of the results are important for the contribution of the topic, but, many times, the scientific production does not offer data clearly and objectively in the methodology and operational data of study. Furthermore, the fact that the research is local makes it impossible to verify the panorama of judicialization globally, which shows restricted results.

Other issues also interfere in the research, since the search for the Brazilian judiciary body to solve conflicts relating to health is not a reality for all the social and regional segments of the country. With this, one realizes that most studies are centered in regions with developed administrative structure.

There are regions with poor infrastructure and that are distant of bodies of judiciary power, which hampers the access of the population. Furthermore, in many cases, filling a lawsuit is expensive, which creates obstacles for users, who end up not claiming their rights. There is also the question of lack of information and instruction, which prevent the access of the user to Justice.

Thus, in most cases, the reality of this population does not appear in researchers in order to know the Brazilian panorama, since the applicants who seek the judiciary power to solve questions linked to health are people with high economic conditions, satisfactory level of instruction and who live in places with easy access to judicial bodies.

Therefore, it can be said that such questions highlight the limitations of the research. The judicialization of health does not reflect the reality of all the Brazilian population, due to the territorial extension of the country, to social and economic differences, as well as the reduced number of judicial bodies in some regions.

\section{Contributions to the field of nursing}

The study will help administrators identify the demands related to health products and services claimed in court, in order to allow the restructuring of the administrative sphere and to provide quality care. For the scientific community, there are elements that add and point to knowledge available in the fields of Law and Health, especially regarding the infraction to the rights of the users of private health plans, which reflect in the effectiveness and efficiency of the service to the population.

\section{FINAL CONSIDERATIONS}

The analysis of the publications regarding judicial demands related to the violation of the rights of the client who uses private health plans allowed to know elements that aggregate and point to a knowledge available in the fields of Law and Health, as well as the main judicial demands formulated. Thus, the judicial demands asking for provision of medicines are predominant. Secondly are the requests for diagnostic procedures; outpatient care; hospitalization in ICU; food formulas; and disposable diapers. Then, there are the requirements for admission in wards and, in a smaller and equal percentage, lawsuits of surgical procedures, OPSM, among others. In this way, the results show the prevalence of legal disputes arising from the failure in providing health service by the private health insurance plans, making it easier for the administrators to identify the sought health products and services in order to reorganize the administrative sphere and to provide quality care.

The judicial demands are in the products, such as OPSM. In health services, namely: procedure; examination; general and specialized consultations; and hospital beds (including ICU). In other factors, there is the resource allocation and interconnection between the three powers. These demands result from the violation to the rights of the client who uses private health insurance plans, which are included in scientific productions.

Therefore, it is stated that, among the data shown on the health product and service, and other factors, the relevance is in the frequency related to health services with N 8, totaling $100 \%$, considering the eight specified items, which are subdivided in: medication; hospital beds for hospitalization in wards and ICU; diagnostic and surgical procedures; general and specialized consultations; food formulas; and diapers.

These data reflect the lack of access of users to health products and services that are the responsibility of the executive power, regardless of whether the user is directly linked with a health insurance plan or SUS, when considering the principles of the public system as universality, integrality and equity.

So, in front of the thematic field of health law and judicialization of health, the judicial demands resulting from health insurance plans are centered within the experienced obstacle in general, both in private insurance plans and in public health. The state must be organized to implement the right to health, either through prevention or through system recovery, so that it works in order to meet the real needs that the society desires.

\section{REFERENCES}

1. Ministério da Saúde (BR). Lei no 8.080, de 19 de setembro de 1990. Dispõe sobre as condições para a promoção, proteção e recuperação da saúde, a organização e o funcionamento dos serviços correspondentes e dá outras providências [Internet]. Diário Oficial da União, Brasília, 1990 Sept 20. Brasília: Ministério da Saúde; 1990 [cited 2015 Aug 18]. Available from: http://conselho.saude.gov.br/legislacao/ lei8080_190990.htm

2. Silva Jr NN. Segunda dimensão dos direitos fundamentais. Âmbito Jurídico [Internet]. 2010 [cited 2015 Aug 18];13(74). Available from: http://www.ambito-juridico.com.br/site/index.php?n_link=revista_artigos_leitura\&artigo_id=7433

3. Senado Federal (BR). Constituição da República Federativa do Brasil [Internet]. Brasília: Senado Federal; 1988 [cited 2017 Dec 05]. Available from: https://www2.senado.leg.br/bdsf/bitstream/handle/id/518231/CF88_Livro_EC91_2016.pdf 
4. Governo Federal. Casa Civil (BR). Lei nº. 8142, de 28 de dezembro de 1990. Dispõe sobre a participação da comunidade na gestão do Sistema Único de Saúde (SUS) e sobre as transferências intergovernamentais de recursos financeiros na área da saúde e dá outras providências [Internet]. Diário Oficial da União, Brasília, 1990 Dec 31. Brasília: Casa Civil; 1990 [cited 2017 Dec 05]. Available from: http:// www.planalto.gov.br/ccivil_03/leis/L8142.htm

5. Paim JS. O que é o SUS? Rio de Janeiro: Editora Fiocruz; 2015.

6. Casa Civil (BR). Lei no 9.656, de 3 de junho de 1998. Dispõe sobre os planos e seguros privados de assistência à saúde. Diário Oficial da União, 1998 June 04. Brasília: Casa Civil; 1998 [cited 2017 Dec 05]. Available from: http://www.planalto.gov.br/ccivil_03/LEIS/L9656.htm

7. Casa Civil (BR). Medida Provisória n. 2.177-44, de 24 de agosto de 2001. Altera a Lei no 9.656, de 3 de junho de 1998, que dispõe sobre os planos privados de assistência à saúde e dá outras providências [Internet]. Diário Oficial da União, Brasília, 2001 Spet 24. Brasília: Casa Civil; 2001 [cited 2017 Dec 05]. Available from: http://www.planalto.gov.br/ccivil_03/MPV/2177-44.htm

8. Agência Nacional de Saúde Suplementar (ANS). ANS 18 anos [Internet]. Brasília: ANS; 2018 [cited 2018 Dec 09]. Available from: http://www. ans.gov.br/

9. Silva LC. Judicialização da saúde: em busca de uma contenção saudável. Âmbito Jurídico [Internet]. 2013 [cited 2015 Aug 18];16(112). Available from: http://www.ambito-juridico.com.br/site/index.php?n_link=revista_artigos_leitura\&artigo_id=13182\&revista_caderno=9

10. Supremo Tribunal de Justiça (STJ). Jurisprudência do STJ. Brasília: STJ; 2017 [cited 2017 Dec 05]. Available from: http://www.stj.jus.br/SCON/

11. Mendes KDS, Silveira RCCP, Galvão CM. Revisão integrativa: método de pesquisa para a incorporação de evidências na saúde e na enfermagem. Texto Contexto Enferm. 2008;17(4):758-64. doi: 10.1590/S0104-07072008000400018

12. Martins PRN, Dahinten BF, Dahinten AF. O problema envolvendo as OPMEs e os planos de saúde: contornos e análise da problemática. Rev Direito Sanit. 2016;17(1):145-66. doi: 10.11606/issn.2316-9044.v17i1p145-166

13. Luzuriaga MJ, Spinelli H. Las denuncias de los afiliados de las empresas de medicina prepaga presentadas ante la Subsecretaría de Defensa del Consumidor en Argentina, 2000-2008. Cad Saúde Pública. 2014;30(5):972-82. doi: 10.1590/0102-311X00136313

14. Silva Jr GB, Dias ER. Avaliação da satisfação dos usuários de um serviço de saúde público-privado no nordeste do Brasil e a judicialização da saúde. Rev Direito Sanit. 2016;17(2):13-29. doi: 10.11606/issn.2316-9044.v17i2p13-29

15. Asensi F, Pinheiro R. Judicialização da saúde e diálogo institucional: a experiência de Lages (SC). Rev Direito Sanit. 2016;17(2):48-65. doi: 10.11606/issn.2316-9044.v17i2p48-65

16. Machado TRC. Judicialização da saúde: analisando a audiência pública no Supremo Tribunal Federal. Rev Bioét. 2014;22(3):561-8. doi: $10.1590 / 1983-80422014223039$

17. Gomes FFC, Cherchiglia ML, Machado CD, Santos VC, Acurcio FA, Andrade EIG. Acesso aos procedimentos de média e alta complexidade no Sistema Único de Saúde: uma questão de judicialização. Cad Saúde Pública. 2014;30(1):31-43. doi: 10.1590/0102-311X00176812

18. Aith F, Dallari SG, Nascimento PR, Bujdoso Y. Os princípios da universalidade e integralidade do SUS sob a perspectiva da política de doenças raras e da incorporação tecnológica. Rev Direito Sanit. 2014;15(1):10-39. doi: 10.11606/issn.2316-9044.v15i1p10-39

19. Wang DWL, Vasconcelos NP, Oliveira VE, Terrazas FV. Os impactos da judicialização da saúde no município de São Paulo: gasto público e organização federativa. Rev Adm Pública. 2014;48(5):1191-206. doi: 10.1590/0034-76121666

20. Carvalho EC, David HMSL. Judicialization of health problem and solution: issues for nursing. Rev Enferm UERJ [Internet]. 2013 [cited 2017 Dec 05];21(4):546-50. Available from: https://www.e-publicacoes.uerj.br/index.php/enfermagemuerj/article/view/10015

21. Leite SN, Schaefer C, Fittkau K. Judicial litigations and social welfare: access to medicines in two towns in the Santa Catarina State, Brazil. Acta Sci Health Sci. 2012;34(spe):295-301. doi: 10.4025/actascihealthsci.v34ispec.10084

22. Boing A, Bloemer NS, Fernandes S, Roeler C. A judicialização do acesso aos medicamentos em Santa Catarina: um desafio para gestão do sistema de saúde. Rev. direito sanit. 2013 Mar-June;14(1):82-97.

23. Oliveira RG, Souza AIS. O perfil das demandas judiciais por direito à saúde pública do município de Leopoldina-MG. Gerais Rev. Saúde Pública SUS MG. 2014;2(2):35-45.

24. Ramos RS, Gomes AMT. A judicialização da saúde pública no Brasil: um estudo de representações sociais. Rev Cuid. 2014;5(2):827-36. doi: 10.15649/cuidarte.v5i2.124

25. Ramalho BA. A interface institucional entre a ANS e o poder judiciário: análise de acórdãos sobre a cobertura de emergências médicas em planos de saúde. Rev Direito Sanit. 2016;17(1):122-44. doi: 10.11606/issn.2316-9044.v17i1p122-144

26. Cabral I, Rezende LF. Análise das ações judiciais individuais para fornecimento de medicamentos em São João da Boa Vista. Rev Direito Sanit. 2015;16(1):59-77. doi: 10.11606/issn.2316-9044.v16i1p59-77

27. Organização Mundial de Saúde (OMS). Constituição da Organização Mundial de Saúde (OMS) [Internet]. Genebra: OMS; 1946 [cited 2019 Feb 20]. Available from: http://www.direitoshumanos.usp.br/index.php/OMS-Organiza\%C3\%A7\%C3\%A3o-Mundial-da-Sa\%C3\%BAde/ constituicao-da-organizacao-mundial-da-saude-omswho.html 